\title{
Residual ß-cell function and microvascular complications in type 1 diabetic patients
}

M.B. Gomes ${ }^{1}$, M.F.R. Gonçalves ${ }^{1}$, R. Neves ${ }^{2}, C$. Cohen ${ }^{3}$ and F.M. Albanesi ${ }^{3}$

\author{
Disciplinas de ${ }^{1}$ Diabetes e M etabologia, ${ }^{2} \mathrm{O}$ ftalmologia and \\ ${ }^{3}$ Cardiologia, U niversidade do Estado do Rio de Janeiro, \\ Rio de Janeiro, RJ, Brasil
}

\section{Correspondence \\ M.B. Gomes \\ Estrada Barra, 1006, BI. 3/502 \\ 22648-900 Rio de Janeiro, RJ \\ Brasil \\ Fax: +55-21-204-2343}

Research supported by CNPq (No. 520.118/94). C. Cohen is the recipient of a CAPES fellowship.

Received September 9, 1998 Accepted January 3, 2000

\section{Abstract}

To determine the influence of residual B-cell function on retinopathy and microalbuminuria we measured basal C-peptide in 50 type 1 diabetic outpatients aged $24.96 \pm 7.14$ years, with a duration of diabetes of $9.1 \pm 6.2$ years. Forty-three patients (86\%) with low Cpeptide $(<0.74 \mathrm{ng} / \mathrm{ml})$ had longer duration of diabetes than 7 patients (14\%) with high C-peptide $(\geq 0.74 \mathrm{ng} / \mathrm{ml})(9$ (2-34) vs 3 (1-10) years, $\mathrm{P}=0.01)$ and a tendency to high glycated hemoglobin $\left(\mathrm{HBA}_{1}\right)(8.8(6-$ $17.9)$ vs $7.7(6.9-8.7) \%, \mathrm{P}=0.08)$. Nine patients $(18 \%)$ had microalbuminuria (two out of three overnight urine samples with an albumin excretion rate $(A E R) \geq 20$ and $<200 \mu \mathrm{g} / \mathrm{min}$ ) and $13(26 \%)$ had background retinopathy. No association was found between low $\mathrm{C}$ peptide, microalbuminuria and retinopathy and no difference in basal C-peptide was observed between microalbuminuric and normoalbuminuric patients $(0.4 \pm 0.5$ vs $0.19 \pm 0.22 \mathrm{ng} / \mathrm{ml}, \mathrm{P}=0.61)$ and between patients with or without retinopathy $(0.4 \pm 0.6$ vs $0.2 \pm 0.3 \mathrm{ng} / \mathrm{ml}, \mathrm{P}=$ $0.43)$. Multiple regression analysis showed that duration of diabetes $(\mathrm{r}$ $\left.=0.30, \mathrm{r}^{2}=0.09, \mathrm{P}=0.031\right)$ followed by $\mathrm{HBA}_{1}\left(\mathrm{r}=0.41, \mathrm{r}^{2}=0.17, \mathrm{P}\right.$ $=0.01)$ influenced basal C-peptide, and this duration of diabetes was the only variable affecting AER $\left(r=0.40, r^{2}=0.16, P=0.004\right)$. In our sample of type 1 diabetic patients residual $\beta$-cell function was not associated with microalbuminuria or retinopathy.

\section{Introduction}

The measurement of C-peptide in type 1 diabetic patients is an important method for estimating residual $ß$-cell function (1). Although the majority of type 1 diabetic patients have only traces of C-peptide after 6-8 years of diabetes, in some patients a detectable level of C-peptide could be observed

\section{Key words}

- C-peptide

- Microalbuminuria

- Retinopathy

- Diabetes type 1 
yielded conflicting results probably because the relationship of C-peptide secretion to diabetic complications independent of glycemic control is difficult to establish (5). However, recent studies have demonstrated that $\mathrm{C}$-peptide administration to type 1 diabetic patients could improve glomerular filtration rate (6), microalbuminuria (7) and autonomic nerve function (8), with no significant influence on glycemic control (8). These actions indicate that $\mathrm{C}$-peptide could be biologically active.

The purpose of the present study was to determine the association of basal C-peptide levels with the frequency of microalbuminuria and retinopathy among a subset of type 1 diabetic patients and also to analyze the possible factors associated with basal Cpeptide levels.

\section{Subjects and Methods}

\section{Subjects}

We studied 50 type 1 diabetic outpatients (22 males, 28 females) regularly attending the diabetes clinic at the State University of Rio de Janeiro, aged $24.96 \pm 7.14$ years, with a disease duration of $9.1 \pm 6.2$ years (11 patients $<5$ years, $18 \geq 5$ and $<10$ years, and $21 \geq 10$ years). The patients were asked to provide three accurately timed overnight urine samples over a period of six months. All patients studied were insulin dependent since diagnosis but none of them had symptoms of diabetes decompensation or were taking antihypertensive medication. All patients were instructed to collect urine under their usual conditions, avoiding intensive physical activity. Normal serum creatinine and normal urinary sediments were used to exclude overt renal disease. All patients took their usual dose of insulin after blood collection. The experimental protocol was approved by the local Ethics Committee and informed consent was obtained from all participants.

\section{Methods}

The albumin excretion rate (AER) was determined in timed overnight urine samples. All urine samples were collected into containers without a preservative. Urine volume was recorded and urine aliquots were stored in glass tubes at $-20^{\circ} \mathrm{C}$ until analysis (within one month). Fasting blood samples were also obtained for C-peptide, glucose, and glycated hemoglobin $\left(\mathrm{HBA}_{1}\right)$ determinations. $\mathrm{C}$-peptide concentrations were measured by radioimmunoassays in sera stored at $-20^{\circ} \mathrm{C}$ for up to 3 months (Diagnostic Product Corporation, Los Angeles, CA, USA), after removal of insulin antibodies by precipitation with polyethylene glycol (PEG). The lower limit of detection of this assay is $0.05 \mathrm{ng} / \mathrm{ml}$. The inter- and intra-assay coefficients of variation were 10 and $7 \%$, respectively. Urine albumin concentration was estimated by double antibody radioimmunoassay (Diagnostic). This method has a sensitivity of 0.3 $\mu \mathrm{g} / \mathrm{ml}$, and in our laboratory interassay and intra-assay coefficients of variation were 3.5 and $2.7 \%$, respectively. Microalbuminuria was defined as an AER $>20 \mu \mathrm{g} / \mathrm{min}$ and $<200 \mu \mathrm{g} / \mathrm{min}$ in at least two out of three overnight urine specimens. Each urine specimen was tested for bacteriuria and if this was more than $100,000 / \mathrm{mm}^{3}$ the urine was discarded. $\mathrm{HBA}_{1}$ was determined by cation exchange chromatography (Boehringer-Mannheim, Mannheim, Germany; reference range 4.5-8\%), and fasting blood glucose (FBG) was measured by the glucose oxidase method (Cobas - Mira Roche, Reutkroz, Switzerland). Retinopathy was assessed by fundoscopy through a dilated pupil by ophthalmoscopy performed by the same ophthalmologist and patients were classified into groups according to degree of retinopathy (normal, background, proliferative). The most seriously affected eye was used for evaluation.

Weight and height were measured to the nearest $0.1 \mathrm{~kg}$ and $0.1 \mathrm{~cm}$, respectively. Body mass index (BMI, $\mathrm{kg} / \mathrm{m}^{2}$ ) was calculated 
from these measurements. The daily insulin dose was also recorded.

\section{Statistical analysis}

The Mann-Whitney U-test was used for comparisons between groups and the Fisher exact test was used for other comparisons. For stepwise multiple and univariate regression analysis, AER and all the variables not normally distributed were log transformed. For statistical analysis, C-peptide levels below the detection limit of the assay were assigned a value of $0.05 \mathrm{ng} / \mathrm{ml}$. Patients were divided into three groups according to basal C-peptide level: undetectable $(<0.05$ $\mathrm{ng} / \mathrm{ml})$, low ( $\geq 0.05$ and $<0.74 \mathrm{ng} / \mathrm{ml})$ and high $(\geq 0.74 \mathrm{ng} / \mathrm{ml})$. This classification was based on our previous observation that $100 \%$ of a nondiabetic comparison group had basal C-peptide level $\geq 0.74 \mathrm{ng} / \mathrm{ml}$ which was the mean minus two standard deviations for this group (9). The mean intraindividual coefficient of variation for AER was also calculated. Stepwise multiple regression analysis was performed on the pooled diabetic group using two models: one with AER and the other with basal C-peptide as the dependent variable. The independent variables selected were age, age at diagnosis, duration of diabetes, daily insulin dose, BMI, FBG and $\mathrm{HBA}_{1}$. Basal C-peptide was also entered as an independent variable in the model with AER as the dependent variable. Stepwise multiple logistic regression analyses were performed to investigate the risk factors for retinopathy with duration of diabetes, $\mathrm{C}$ peptide level, AER, $\mathrm{HBA}_{1}$ as independent variables. The odds ratio was given with $95 \%$ confidence limits (CL). These analyses were performed using SPSS (version 6.0) and EPI INFO (version 6.0). Values are reported as means \pm SD for normally distributed data and as medians (minimum/maximum) for skewed data. The significance level to be considered was $95 \%$ and the statistical power $80 \%$.

\section{Results}

Type 1 diabetic patients showed a median C-peptide level of $0.2 \mathrm{ng} / \mathrm{ml}(0.05-2.6)$. Nineteen (38\%), $24(48 \%)$ and 7 patients (14\%), respectively, showed undetectable, low and high C-peptide levels. Since we did not find differences between the patients with undetectable and low C-peptide in any variable analyzed, the two groups were combined into one (low C-peptide level). The group of low C-peptide levels had a higher duration of diabetes than the group with high C-peptide levels (9 (2-34) vs 3 (1-10) years, $\mathrm{P}=0.01)$. We observed a tendency to high $\mathrm{HBA}_{1}$ levels in the low C-peptide group compared with the high $\mathrm{C}$-peptide group (8.8 (6-17.9) vs 7.7 (6.9-8.7)\%, $\mathrm{P}=0.08)$. No difference was found between groups concerning gender, age, age at diagnosis, daily insulin dose or BMI.

No association was noted between low C-peptide level and the frequency of microalbuminuria or retinopathy. The clinical characteristics of type 1 diabetic patients defined by C-peptide level are shown in Table 1. A total of 9 patients (18\%) (4 females and 5

Table 1 - Clinical characteristics of 50 type 1 diabetic patients classified by C-peptide level.

Data for duration of diabetes, $\mathrm{AER}$ and $\mathrm{HBA}_{1}$ are reported as medians (minimum/ maximum). The other data are reported as means \pm SD. Mann-Whitney U-test was used for comparison between groups (two-sided $\mathrm{P}<0.05$ ). Fisher's exact test was used for comparison between categorical data. BMI, Body mass index; FBG, fasting blood glucose; $\mathrm{AER}$, albumin excretion rate; $\mathrm{HBA}_{1}$, glycated hemoglobin.

\begin{tabular}{lccc}
\hline Variable & $\begin{array}{c}\text { C-peptide } \\
<0.74 \mathrm{ng} / \mathrm{ml}\end{array}$ & $\begin{array}{c}\text { C-peptide } \\
\geq 0.74 \mathrm{ng} / \mathrm{ml}\end{array}$ & $\begin{array}{c}\text { Significance } \\
\text { level }(\mathrm{P})\end{array}$ \\
\hline Number (\%) & $43(86)$ & $7(14)$ & - \\
Gender (males/females) & $20 / 23$ & $2 / 5$ & 0.27 \\
Age (years) & $25.3 \pm 7.1$ & $23 \pm 7.7$ & 0.5 \\
Age at diagnosis (years) & $15.4 \pm 8.5$ & $18.7 \pm 5.3$ & 0.2 \\
Duration of diabetes (years) & $9(2-34)$ & $3(1-10)$ & 0.01 \\
Insulin dose (U/kg) & $0.9 \pm 0.4$ & $0.8 \pm 0.4$ & 0.3 \\
BMI (kg/m²) & $22 \pm 2.5$ & $21 \pm 1.6$ & 0.2 \\
FBG (mg/dl) & $247.2 \pm 100.4$ & $195.7 \pm 83.4$ & 0.14 \\
HBA $(\%)$ & $8.8(6-17.9)$ & $7.7(6.9-8.7)$ & 0.08 \\
AER ( $\mu$ g/min) & $8(2.1-164.7)$ & $6.1(0.9-25.3)$ & 0.14 \\
Microalbuminuria (yes/no) & $8 / 35$ & $1 / 6$ & 0.6 \\
Retinopathy (yes/no) & $12 / 31$ & $1 / 6$ & 0.4
\end{tabular}


males) were considered microalbuminuric. Mean intraindividual coefficient of variation in AER was $55.4 \%$. No difference in basal C-peptide level was observed between microalbuminuric and normoalbuminuric patients $(0.4 \pm 0.5$ vs $0.19 \pm 0.22 \mathrm{ng} / \mathrm{ml}, \mathrm{P}=$ $0.61)$.

A total of 13 patients (26\%) (7 females and 6 males) had background retinopathy. No proliferative retinopathy was observed. No difference in basal C-peptide level was observed between patients with or without retinopathy $(0.4 \pm 0.6 v s 0.2 \pm 0.3 \mathrm{ng} / \mathrm{ml}, \mathrm{P}=$ $0.43)$.

The results of univariate analysis are shown in Table 2. In the stepwise multiple regression analysis with basal C-peptide level as the dependent variable, duration of diabetes (step $1\left(\mathrm{r}=0.30, \mathrm{r}^{2}=0.09, \mathrm{P}=0.031 ; \beta\right.$ coefficient $(95 \% \mathrm{CL})=-0.47(-0.90 /-0.04))$ and $\mathrm{HBA}_{1}\left(\right.$ step $2\left(\mathrm{r}=0.41, \mathrm{r}^{2}=0.17, \mathrm{P}=\right.$ 0.01 ; $\beta$ coefficient $(95 \%$ CL) -1.69 (-3.18/ $-0.20)$ ) were the only significant variables. Duration of diabetes was the only significant independent variable $\left(\mathrm{r}=0.40, \mathrm{r}^{2}=0.16, \mathrm{P}=\right.$ 0.004; $\beta$ coefficient (95\% CL) 0.53 (0.18/ $0.89)$ ) in the stepwise multiple regression analysis performed with AER as a dependent variable. In multiple logistic regression analysis with retinopathy as a dependent variable, AER yielded a marginally significant odds ratio of 1.03 (95\% CL), 0.99-1.06; $\beta$ coefficient $=0.0286$; Wald 3.10.

\section{Discussion}

Most type 1 diabetic patients (86\%) had a

Table 2 - Univariate regression analysis of C-peptide level against clinical and laboratory data.

AER, Albumin excretion rate.

\begin{tabular}{lcccc}
\hline Variable & $r$ & $r^{2}$ & B coefficient & P value \\
\hline Duration of diabetes (years) & -0.30 & 0.09 & -0.5 & 0.01 \\
Insulin dose (U/kg) & -0.27 & 0.07 & -1.5 & 0.06 \\
AER $(\mu \mathrm{g} / \mathrm{min})$ & -0.30 & 0.09 & -0.36 & 0.03
\end{tabular}

low level of basal C-peptide. However, in 7 patients (14\%) a high level of basal C-peptide was observed. This suggests that some type 1 diabetic patients may retain some insulin secretory capacity (3). Total or partial diabetes remission in these patients seems improbable because no discontinuation or a $50 \%$ decrease of total daily insulin dose since diagnosis of diabetes was noted in any of them (10). Although we did not perform a stimulation test to assess residual ß-cell function, the cut-off value of $0.74 \mathrm{ng} / \mathrm{ml}$ was similar to others reported thus far, i.e., 0.6 (5), and 0.79 (11) which were used to discriminate patients concerning the presence or absence of residual ß-cell function. Previous studies have observed a close correlation between fasting and stimulated C-peptide levels in type 1 diabetic patients but there is no agreement about which is the best stimulus and criterion to be used in the stimulation test to characterize residual $\beta$-cell function $(4,5,9)$. In agreement with other studies, these seven patients had a short duration of diabetes and a tendency to better metabolic control $(1,5)$. Since our sample mostly comprised pubertal and young adults we did not find the correlation between basal C-peptide and age described in many other reports $(1,3,12)$.

Although we noted a tendency to a negative correlation between basal C-peptide and daily insulin dose in univariate analysis, stepwise multiple regression analysis showed that duration of diabetes was the most important variable influencing C-peptide levels, followed by $\mathrm{HBA}_{1}$, as also reported by others with respect to basal (5) and stimulated C-peptide $(1,5)$.

Although we observed a negative correlation between basal C-peptide and AER in univariate analysis, duration of diabetes was the only significant independent variable in stepwise multiple regression. In multiple logistic regression with retinopathy as a dependent variable, only AER appeared to be a risk factor but yielded a marginally signifi- 
cant odds ratio.

Although our data also suggest that endogenous insulin secretion estimated by basal C-peptide had no association with microalbuminuria or retinopathy, two points concerning our patients should be discussed. First, our sample comprised mostly young patients with a relatively short duration of diabetes (58\% with $<10$ years) and consequently we had only 7 and 13 patients with microalbuminuria and retinopathy, respectively. The second point was the small number of patients $(\mathrm{N}=7)$ with high basal $\mathrm{C}$ peptide levels. For an $80 \%$ statistical power a sample comprising 92 patients would be necessary to avoid a type 2 statistical error which may have occurred with our sample. Even though these facts could have influenced our results, a prospective study with different types of diabetes has not demonstrated an effect of higher levels of basal Cpeptide on 6-year progression of retinopathy in younger onset insulin-dependent patients (4). The level of glycemic control was the most important predictor of the incidence of retinopathy (4). Another 2-year prospective study with type 1 diabetics also did not find an influence of stimulated C-peptide on the evolution of retinopathy and/or microalbuminuria (13). Since we found a negative correlation between basal C-peptide and $\mathrm{HBA}_{1}$, it is possible that low basal C-peptide levels could be associated with difficulty in achieving a good metabolic control and may influence the development of diabetic complications. However, since $\mathrm{HBA}_{1}$ was not a significant independent variable in stepwise multiple regression analysis with AER as a dependent variable probably because of the study design (cross-sectional one), this fact seems improbable. On the other hand, some studies have suggested a protective effect of residual $\beta$-cell function against the onset of nephropathy and/or retinopathy (14-16), including the breakdown of the blood retinal barriers (17). It is important to emphasize that two of these studies $(15,16)$ were done mostly in patients with noninsulin-dependent diabetes.

Homogeneity in the pattern of decline of ß-cell function was observed in a recent prospective study of type 1 diabetic patients followed for up to 7.4 years (12). It was also observed that the type of insulin treatment had no influence on the overall decline of basal and stimulated C-peptide (5). These data suggest that the underlying destructive process affecting $ß$-cells develops faster than the beginning of the pathogenic process of microvascular complications of diabetes.

In conclusion, we found no association between basal C-peptide level, microalbuminuria and retinopathy. A larger sample and also a prospective study on type 1 diabetic patients should confirm if high levels of basal C-peptide have any influence on the development of microvascular complications of diabetes independent of glycemic control.

\section{References}

1. Clarson C, Daneman D, Drash AL, Becker DJ \& Eherlich RM (1987). Residual ß-cell function in children with IDDM : reproducibility of testing and factors influencing insulin secretory reserve. Diabetes Care, 10: 33-38.

2. Ludvigsson J \& Heding LG (1976). C-peptide in children with juvenile diabetes. Diabetologia, 12: 627-630.

3. Madsbad S (1983). Prevalence of residual B-cell function and its metabolic consequences in type 1 (insulin-dependent) dia- betes. Diabetologia, 24: 141-147.

4. Klein R, Klein BEK \& Moss SE (1995). The Wisconsin Epidemiologic Study of Diabetic Retinopathy. The relationship of Cpeptide to the incidence and progression of diabetic retinopathy. Diabetes, 44: 796801.

5. The DCCT Research Group (1987). Effects of age, duration and treatment of insulindependent diabetes mellitus on residual B-cell function: observations during eligibility testing for the diabetes control and complications trial. J ournal of Clinical Endocrinology and Metabolism, 65: 30-35.

6. J ohansson B-L, Sjoberg S\& Wahren J (1992). The influence of C-peptide on renal function and glucose utilization in type 1 (insulin-dependent) diabetic patients. Diabetologia, 35: 121-128.

7. J ohansson B-L, Forbes EF \& Wahren J (1995). Effects of C-peptide on nephropathy and neuropathy in IDDM patients - a clinical study. Diabetes, 44 (Suppl 1): 33 A. 
8. J ohansson B-L, Linde B \& Wahren J (1992). Effects of C-peptide on blood flow, capillary diffusion capacity and glucose utilization in the exercising forearm in type 1 (insulin-dependent) diabetic patients. Diabetologia, 35: 1151-1158.

9. Pozzan R, Dimetz T, Gazzola HM \& Gomes MB (1997). Discriminative capacity of fasting C-peptide levels in a functional test according to different criteria of response to a stimulus. Acta Diabetologica, 34: 42-45.

10. Agner T, Damm P \& Binder C (1987). Remission in IDDM: prospective study of basal C-peptide and insulin dose in 268 consecutive patients. Diabetes Care, 10: 164-169.

11. Maislos $M$, Bonder-Fishman B \&
Weitzman S (1994). Prevalence and clinical characteristics of type I and II insulintreated diabetes in the community. Diabetes Care, 17: 1230-1231.

12. Snorgaard O, Lassen LH \& Binder C (1992). Homogeneity in pattern of decline of ß-cell function in IDDM. Diabetes Care, 15: 1009-1013.

13. Winocour $\mathrm{PH}$, J eacock J, Kalsi $\mathrm{P}$, Gordon $C \&$ Anderson DC (1990). The relevance of persistent C-peptide secretion in type 1 (insulin-dependent) diabetes mellitus to glycaemic control and diabetic complications. Diabetes Research and Clinical Practice, 9: 23-35.

14. Sjoberg $S$, Gjotterberg $M$, Lefvert $A K$, Gunnarsson R \& Ostman J (1986). Significance of residual insulin production in long-term type I diabetes mellitus. Transplantation Proceedings, 18: 1498-1499.

15. Moster MA (1984). Circulating C-peptide and diabetic retinopathy. Diabetes Research, 1: 151-154.

16. Suzuki K, Watanabe K, Motegi $T \&$ Kajinuma H (1989). High prevalence of proliferative retinopathy in diabetic patients with low pancreatic ß-cell capacity. Diabetes Research and Clinical Practice, 6: 45-52.

17. Kernell A, Ludvigsson J \& Finnstrom K (1990). Vitreous fluorophotometry in juvenile diabetics with and without retinopathy in relation to metabolic control insulin antibodies and C-peptide levels. Acta Ophthalmologica, 68: 415-420. 